\section{Terakreditasi}

Ditjen Penguatan Riset dan Pengembangan, Kemenristekdikti

Keputusan No: 21/E/KPT/2018, Tanggal 9 Juli 2018
September 2018, 5(3):67-72

http://ojs.uho.ac.id/index.php/peternakan-tropis

\title{
Penampilan Produksi Sapi Aceh Umur Satu Hari, Umur Sapih, dan Umur Satu Tahun
}

\author{
Ikhsanuddin $^{1^{*}}$, V.M. Ani Nurgiartiningsih ${ }^{2}$, Kuswati $^{2}$, Mukhtar $^{3}$ \\ ${ }^{1}$ Mahasiswa Program Pascasarjana Fakultas Peternakan Universitas Brawijaya \\ ${ }^{2}$ Dosen Fakultas Peternakan Universitas Brawijaya, \\ Jl. Veteran, Malang 65145 \\ ${ }^{3}$ Balai Pembibitan Ternak Unggul dan Hiajuan Pakan Ternak Indrapuri, \\ Jl.Banda Aceh - Medan Km. 25 Desa Reukih Dayah, Kec. Indrapuri Kab. Aceh Besar. 23373 \\ *Email korespondensi: ixaniksann@gmail.com
}

\begin{abstract}
ABSTRAK
Penelitian ini bertujuan untuk mengetahui penampilan produksi sapi aceh di BPTU-HPT Indrapuri Aceh. Materi penelitian yaitu sapi aceh umur satu hari, umur sapih, dan umur satu tahun sebanyak 159 ekor. Metode penelitian adalah studi kasus berdasarkan data bobot lahir, bobot sapih, bobot satu tahun beserta ukuran tubuhnya. Data dianalisis menunjukkan bahwa sapi jantan memiliki bobot lahir 13,66 $\pm 1,08 \mathrm{~kg}$, bobot umur 205 hari $71,60 \pm 7,92 \mathrm{~kg}$ dan bobot umur 365 hari $104,66 \pm 11,72 \mathrm{~kg}$. Sapi betina memiliki bobot lahir 13,88 $\pm 1,32 \mathrm{~kg}$, bobot umur 205 hari $64,38 \pm 10,36$ $\mathrm{kg}$ dan bobot umur 365 hari 90,29 $\pm 11,95 \mathrm{~kg}$. Sapi Aceh umur satu hari memiliki lingkar dada, panjang badan dan tinggi pundak berturut-turut $55,41 \mathrm{~cm}, 46,16 \mathrm{~cm}$ dan $55,22 \mathrm{~cm}$ pada sapi jantan serta 55,87 $\mathrm{cm}, 46,83 \mathrm{~cm}$, dan 55,74 cm pada sapi betina. Sapi aceh umur 365 hari memiliki ukuran lingkar dada, panjang badan dan tinggi pundak berturut-turut $114,32 \mathrm{~cm}, 94,31 \mathrm{~cm}$ dan $92,93 \mathrm{~cm}$ pada sapi jantan serta $104,25 \mathrm{~cm}, 85,06$ dan $87,71 \mathrm{~cm}$ pada sapi betina. Rata-rata penampilan produksi sapi aceh di BPTU Indrapuri berpotensi menjadi ternak unggul berdasarkan kriteria SNI.
\end{abstract}

Kata Kunci: sapi aceh, penampilan produksi, bobot badan, ukuran tubuh

\begin{abstract}
This study aimed to evaluate the productive performance of aceh cattle at Indrapuri Breeding Center for Superior Livestock and Forage. A total of 159 heads of aceh cattle were used in this study. The method used was a case study based on the data of birth weight, weaning weight, yearling weight, and body size. The results showed that the birth weight, weaning weight at 205 days of age, and yearling weight at 365 days of age of male aceh cattle were $13.66 \pm 1.08 \mathrm{~kg}, 71.60 \pm 7.92 \mathrm{~kg}$, and $104.66 \pm 11.72$ $\mathrm{kg}$, respectively. Whereas, female aceh cattle had the birth weight, weaning weight at 205 days of age, and yearling weight at 365 days of age of $13.88 \pm 1.32 \mathrm{~kg}, 64.38 \pm 10.36 \mathrm{~kg}$, and $90.29 \pm 11.95 \mathrm{~kg}$, respectively. At birth, male Aceh cattle had the chest circumference, body length, and shoulder height of $55.41 \mathrm{~cm}, 46.16 \mathrm{~cm}$, and $55.22 \mathrm{~cm}$, respectively, while female aceh cattle were $55.87 \mathrm{~cm}, 46.83 \mathrm{~cm}$, and $55.74 \mathrm{~cm}$, respectively. At 365 days of age, male aceh cattle had the chest circumference, body length, and shoulder height of $114.32 \mathrm{~cm}, 94.31 \mathrm{~cm}$, and $92.93 \mathrm{~cm}$, respectively, while female aceh cattle were $104.25 \mathrm{~cm}, 85.06 \mathrm{~cm}$, and $87.71 \mathrm{~cm}$, respectively. The average productive performance of aceh cattle at Indrapuri Breeding Center for Superior Livestock and Forage has the potential to become superior cattle based on the criteria of Indonesian National Standard.
\end{abstract}

Keywords: aceh cattle, performance, body weight, body size 


\section{PENDAHULUAN}

Sapi aceh merupakan salah satu sapi lokal (plasma nutfah) Indonesia yang dilindungi dan sudah ditetapkan rumpunnya oleh Menteri Pertanian dengan nomor ketetapan 2907/Kpts/OT.140/06/2011 dan juga telah ditetapkan Standar Nasional Indonesia (SNI) oleh Badan Standar Nasional nomor 7651.3:2013. Sapi aceh sebagai sumber daya genetik yang wajib dikembangbiakan untuk penyediaan bibit di masa yang akan dating. Sapi aceh termasuk jenis sapi potong dan kerja. Sistem pemeliharaannya dilakukan secara tradisional oleh peternak pedesaan di Propinsi aceh. Sapi aceh memiliki daya adaptasi terhadap lingkungan cukup baik. Berdasarkan penelitian Mukhtar, Jamaliah dan Saumar (2015) menyatakan bahwa sapi aceh memiliki beberapa keistimewaan yaitu; tahan terhadap penyakit di wilayah tropis, mempunyai adaptasi yang baik terhadap iklim ekstrem dan wilayah marginal serta toleran terhadap kualitas nutrisi pakan yang rendah.

Sapi aceh Jantan memiliki tampilan tubuh lebih besar dibandingkan sapi betina. Tubuh bagian depan relatif lebih rendah dibanding bagian belakang baik pada sapi jantan maupun betina. Sapi betina memiliki gumba kecil dan pada sapi jantan bergumba lebih besar serta bergelambir baik pada jantan maupun betina dengan tampilan lebih tebal dan lebih berat pada jantan. Gelambir pada sapi aceh jantan dan betina dijumpai mulai bawah kerongkongan sampai bawah dada antara dua kaki depan. Sapi aceh jantan memiliki selaput penis (preputium) yang pendek (Abdullah, 2008).

Keberadaan sapi aceh sebagai ternak lokal semakin terancam baik dari segi jumlah maupun kemurniannya. Hal ini disebabkan oleh masuknya jenis sapi luar yang tidak terkontrol ke daerah Aceh. Balai Pembibitan Ternak Unggul dan Hijauan Pakan Ternak (BPTUHPT) Indrapuri memiliki tugas pokok dan fungsi sebagai pelaksana pemeliharaan, produksi, pemuliaan dan pengembangan sapi lokal serta melakukan penyebaran dan distribusi bibit sapi lokal. Penelitian ini dilakukan untuk mengetahui performans produksi sapi aceh yang dikembangkan di BPTU-HPT Indrapuri sebagai lembaga yang berperan penting dalam peningkatan kualitas dan kuantitas sapi aceh ke depan.

\section{MATERI DAN METODE}

\section{Materi Penelitian}

Penelitian ini dilakukan di Balai Pembibitan Ternak Unggul dan Hijauan Pakan ternak (BPTU-HPT) Indrapuri. Materi dalam penelitian ini adalah 159 ekor sapi aceh yang terdiri dari 93 ekor sapi jantan dan 66 ekor sapi betina yang merupakan data catatan produksi bobot lahir, bobot sapih dan bobot satu tahun beserta ukuran tubuh.

\section{Koreksi Data}

Bobot badan sapih dikoreksi ke umur 205 hari dan bobot badan satu tahun dikoreksi ke umur 365 hari berdasarkan petunjuk Hardjosubroto (1994) sebagai berikut:

$$
B B_{205}=\left(\frac{B B-B L}{u m u r} \times 205+B L\right) x F K U I
$$

Keterangan:

$\mathrm{BB}_{205}=$ bobot sapih terkoreksi (kg)

$\mathrm{BB}=$ bobot badan pada saat ditimbang

$\mathrm{BL}=$ bobot lahir

Umur = umur saat penimbangan

FKUI $=$ Faktor Koreksi Umur Induk

$$
B B_{365}=\frac{B B-B S}{\text { tenggang waktu }} \times 160+B S_{205}
$$

Keterangan

$\mathrm{BB}_{365}=$ BBobot badan terkoreksi umur 365 hari $(\mathrm{kg})$

BS $=$ bobot saat penyapihan $(\mathrm{kg})$

$\mathrm{BB}=$ bobot badan pada saat ditimbang

Tenggang waktu = tenggang waktu antara penimbangan sekarang dengan saat penyapihan (hari)

Catatan: analisis data ukuran tubuh dikoreksi mengikuti rumus koreksi bobot badan

\section{Pertambahan Bobot Badan Harian}

Pertambahan Bobot Badan Harian (PBBH) adalah rata-rata dari pertambahan bobot badan setiap hari sejak lahir sampai saat hari penimbangan. Berdasarkan petunjuk Hardjosobroto (1994) pertambahan bobot badan harian dapat dihitung dengan rumus.

$$
P B B H \text { prasapih }=\frac{B S-B L}{\text { Tenggang waktu prasapih }}
$$


PBBH Pascasapih $=\frac{B B-B S}{\text { Tenggang waktu pascasapih }}$

Keterangan

$\mathrm{PBBH}=$ Pertambahan Bobot Badan Harian

$\mathrm{BL}=$ bobot lahir

$\mathrm{BS}=$ bobot sapih

$\mathrm{BB}=$ bobot badan pada saat ditimbang

Tenggang waktu prasapih $=$ jarak waktu antara umur satu hari dengan umur sapih (hari)

Tenggang waktu pascasapih = jarak waktu antara umur sapih dengan umur saat penimbangan (hari)

\section{HASIL DAN PEMBAHASAN}

\section{Performans Pertumbuhan}

Performans produksi sapi aceh meliputi

bobot badan dan ukuran tubuh serta
Pertambahan Bobot Badan Harian $(\mathrm{PBBH})$ pra sapih dan pasca sapih disajikan pada Tabel 1 . Performans rata-rata bobot lahir sapi aceh jantan $(13,66 \pm 1,08 \mathrm{~kg})$ dan betina $(13,88 \pm 1,32$ $\mathrm{kg}$ ) tidak berbeda dibandingkan penelitian sebelumnya yang dilakukan oleh Kaswati, Sumadi \& Ngadiono (2013) bahwa bobot lahir sapi aceh 13,52 $\pm 1,74 \mathrm{~kg}$. Sementara untuk sapi madura $(15,74+2,62 \mathrm{~kg})$, PO $(26.10+1.55 \mathrm{~kg})$ jauh lebih besar dibandingkan bobot lahir sapi aceh. Hasil penelitian lain yang dilaporkan Jamaliah \& Marwan (2018) bahwa bobot lahir sapi cceh betina mencapai 13,5 kg. Hasil penelitian tersebut relatif sama dengan hasil penelitian ini. Bobot lahir rata-rata sapi aceh tergolong lebih rendah dibandingkan dengan bobot lahir sapi bali yaitu $18,4 \pm 1,72 \mathrm{~kg}$ (Prasojo, Arifiantini, \& Kusdiantoro, 2010).

Tabel 1. Performans produksi bobot badan, ukuran tubuh dan pertambahan bobot badan harian sapi aceh jantan dan betina

\begin{tabular}{|c|c|c|c|c|}
\hline Variabel & $\begin{array}{c}\mathrm{n} \\
(\text { Jantan})\end{array}$ & $\bar{x} \pm s d$ & $\begin{array}{c}\mathrm{n} \\
\text { (Betina) }\end{array}$ & $\bar{x} \pm s d$ \\
\hline Umur 1 hari & 93 & & 66 & \\
\hline Bobot lahir & & $13,66 \pm 1,08 \mathrm{~kg}$ & & $13,88 \pm 1,32 \mathrm{~kg}$ \\
\hline PBBH prasapih & & $0,28 \pm 0,03 \mathrm{~kg}$ & & $0,25 \pm 0,05 \mathrm{~kg}$ \\
\hline Tinggi pundak & & $55,22 \pm 2,09 \mathrm{~cm}$ & & $55,74 \pm 1,86 \mathrm{~cm}$ \\
\hline Panjang badan & & $46,16 \pm 2,71 \mathrm{~cm}$ & & $46,83 \pm 2,88 \mathrm{~cm}$ \\
\hline Lingkar dada & & $55,41 \pm 2,57 \mathrm{~cm}$ & & $55,87 \pm 2,65 \mathrm{~cm}$ \\
\hline Umur 205 hari & 93 & & 66 & \\
\hline Bobot 205 hari & & $71,60 \pm 7,92 \mathrm{~kg}$ & & $64,38 \pm 10,36 \mathrm{~kg}$ \\
\hline PBBH pascasapih & & $0,21 \pm 0,05 \mathrm{~kg}$ & & $0,16 \pm 0,04 \mathrm{~kg}$ \\
\hline Tinggi pundak & & $87,07 \pm 4,90 \mathrm{~cm}$ & & $81,32 \pm 5,47 \mathrm{~cm}$ \\
\hline Panjang badan & & $80,71 \pm 7,34 \mathrm{~cm}$ & & $75,15 \pm 8,34 \mathrm{~cm}$ \\
\hline Lingkar dada & & $96,13 \pm 7,98 \mathrm{~cm}$ & & $90,98 \pm 8,00 \mathrm{~cm}$ \\
\hline Umur 365 hari & 93 & & 66 & \\
\hline Bobot 365 hari & & $104,66 \pm 11,23 \mathrm{~kg}$ & & $90,29 \pm 11,95 \mathrm{~kg}$ \\
\hline Tinggi pundak & & $95,93 \pm 5,51 \mathrm{~cm}$ & & $87,71 \pm 5,16 \mathrm{~cm}$ \\
\hline Panjang badan & & $94,31 \pm 7,33 \mathrm{~cm}$ & & $85,06 \pm 5,89 \mathrm{~cm}$ \\
\hline Lingkar dada & & $114,32 \pm 8,25 \mathrm{~cm}$ & & $104,25 \pm 7,71 \mathrm{~cm}$ \\
\hline
\end{tabular}

Keterangan: $\overline{\mathrm{x}}=$ rata-rata, $\mathrm{n}=$ jumlah sampel, $\mathrm{sd}=$ standar deviasi

Bobot sapih sapi aceh jantan dan betina

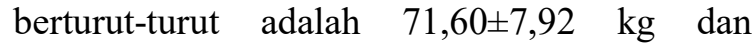
$64,38 \pm 10,36 \mathrm{~kg}$. Hasil penelitian ini berbeda dengan penelitian sebelumnya yang laporkan bobot sapih sapi aceh umur 205 hari pada jantan mencapai 68,74 $\mathrm{kg}$ dan betina $67,99 \mathrm{~kg}$ (Bakhtiar, 2010). Pada umur satu tahun bobot badan sapi aceh mencapai $(104,66 \pm 11,23 \mathrm{~kg})$ pada sapi jantan dan $(90,29 \pm 11,95 \mathrm{~kg})$ untuk sapi betina. Perbedaan bobot sapi jantan dan 
betina disebabkan oleh faktor jenis kelamin. Menurut Phillips (2010) pengaruh pertumbuhan efek jenis kelamin disebabkan oleh hormon seks yaitu androgen terutama hormon testosteron yang diproduksi oleh testes. Hormon ini berperan penting dalam peningkatan efesiensi pertumbuhan dengan peningkatan retensi nitrogen dalam otot.

Penelitian lain yang tergolong tidak berbeda dengan hasil penelitian ini yaitu laporan Jamaliah \& Marwan (2018) bahwa ratarata bobot badan sapi aceh betina umur satu tahun mencapai 90,64 kg. Rata-rata bobot badan satu tahun sapi aceh masih rendah dibandingkan dengan sapi bali. Sapi bali memiliki rata-rata bobot satu tahun mencapai $142,45 \pm 3,25 \mathrm{~kg}$ (Gunawan \& Jakaria, 2011).

Sapi aceh memiliki pertambahan bobot badan harian $(\mathrm{PBBH})$ yang lambat pada fase pasca sapih dibandingkan dengan fase prasapih. Hal ini disebabkan oleh banyak faktor antara lain faktor adaptasi ternak terhadap makanan dan faktor induk. Setelah ternak sapi disapih secara otomatis pedet tidak lagi mendapatkan air susu sehingga berefek terhadap petumbuhan yang lambat pada ternak tersebut. Faktor induk dan sifat keibuan sangat berpengaruh pada pertambahan bobot badan harian prasapih. Sapi aceh tergolong sapi yang naluri sifat keibuan sangat baik, walaupun dalam kondisi kurus, induk sapi tetap menyusui anaknya. Hal inilah yang menyebabkan penurunan pertambahan bobot badan harian fase pasca sapih dibandingkan prasapih. Menurut Kuswati \& Susilawati (2016) pertambahan bobot badan harian ternak tidak hanya dipengaruhi oleh faktor genetik tetapi juga faktor lingkungan terutama pakan, yang menyebabkan variasi pertambahan bobot badan.

Rata-rata ukuran tubuh sapi aceh jantan pada umur satu hari yaitu tinggi pundak $(55,22$ $\pm 2,09 \mathrm{~cm})$, panjang badan $(46,16 \pm 2,71 \mathrm{~cm})$ dan lingkar dada $(55,41 \pm 2,57 \mathrm{~cm})$. Pada sapi betina umur satu hari ukuran tinggi pundak mencapai $(55,74 \pm 1,86 \mathrm{~cm})$, panjang badan $(46,83 \pm 2,88$ $\mathrm{cm})$ dan lingkar dada $(55,87 \pm 2,65 \mathrm{~cm})$. Penampilan ukuran tubuh sapi aceh umur satu hari antara jantan dan betina tergolong tidak berbeda. Besarnya ukuran tubuh sapi betina umur satu hari relatif sama dengan penelitian sebelumnya yang dilaporkan Jamaliah dan Marwan (2018) yaitu rata-rata tinggi pundak (TP) sapi aceh betina pada saat lahir mencapai $56,36 \mathrm{~cm}$, panjang badan $48,77 \mathrm{~cm}$ dan lingkar dada 55,6 cm. Ukuran tubuh sapi aceh umur satu hari lebih rendah dibandingkan sapi madura yang dilaporankan Sulistiyoningtiyas, Nurgiartiningsih \& Ciptadi (2017) bahwa ukuran tubuh sapi madura rata-rata tinggi pundak $64 \pm 4,16 \mathrm{~cm}$, panjang badan $52 \pm 6,25 \mathrm{~cm}$ dan lingkar dada $59 \pm 4,99 \mathrm{~cm}$.

Penampilan ukuran tubuh sapi aceh jantan pada umur 205 hari adalah tinggi pundak $(87,074 \pm 4,90 \mathrm{~cm})$, panjang badan $(80,71 \pm 7,34$ $\mathrm{cm})$ dan lingkar dada $(96,13 \pm 7,98 \mathrm{~cm})$. Untuk sapi betina ukuran tinggi pundak $(81,32 \pm 5,47$ $\mathrm{cm})$, panjang badan $(75,15 \pm 8,34 \mathrm{~cm})$ dan lingkar dada $(90,98 \pm 8,00 \mathrm{~cm})$. Pertumbuhan ukuran tubuh sapi jantan lebih cepat dibandingkan sapi betina menunjukkan bahwa faktor jenis kelamin mempengaruhi laju pertumbuhan ternak. Ukuran tubuh sapi aceh umur 205 hari tergolong lebih rendah dibandingkan sapi bali. Menurut laporan Depision (2010) sapi bali umur 205 hari memiliki ukuran tubuh dengan panjang badan $82,33 \mathrm{~cm}$, tinggi pundak $86,54 \mathrm{~cm}$ dan lingkar dada mencapai $121,57 \mathrm{~cm}$. Faktor rendahnya ukuran tubuh sapi aceh dibandingkan dengan sapi bali disebabkan oleh perbedaan bangsa sapi (genetik) dan lingkungan. Menurut Kurnianto (2009) penampilan sifat kuantitatif ternak dipengaruhi oleh genetik dan lingkungan. Faktor lingkungan terdiri dari pakan, kondisi lingkungan, perlakuan terhadap ternak dan lainlain. Apabila semua faktor lingkungan baik, maka kemampuan produksi dapat diekspresikan secara optimal.

Sapi aceh jantan umur 365 hari memiliki ukuran tubuh dengan tinggi pundak $(95,93 \pm 11,23 \mathrm{~cm})$, panjang badan $(94,31 \pm 7,33$ $\mathrm{cm})$ dan lingkar dada $(114,32 \pm 8,25 \mathrm{~cm})$. BSN (2013) menetapkan standar ukuran tubuh sapi aceh jantan pada umur 24-36 bulan untuk katagori kelas III harus memiliki tinggi pundak minimal $105 \mathrm{~cm}$, panjang badan $107 \mathrm{~cm}$ dan lingkar dada $135 \mathrm{~cm}$. Berdasarkan penelitian, pertumbuhan ukuran tubuh sapi jantan pasca sapih per hari pada lingkar dada $(0,11 \mathrm{~cm})$, panjang badan $(0,08 \mathrm{~cm})$ dan tinggi pundak $(0,05 \mathrm{~cm})$. Berdasarkan pertambahan ukuran tubuh tersebut dapat diasumsikan bahwa sapi jantan pada saat umur 2 tahun akan memiliki ukuran tubuh sesuai dengan SNI katagori kelas II dengan ukuran minimal (lingkar dada 140 $\mathrm{cm}$, panjang badan $113 \mathrm{~cm}$ dan tinggi pundak $109 \mathrm{~cm})$.

Penampilan produksi sapi aceh betina umur 365 hari memiliki tinggi pundak 87,71 $\mathrm{cm}$, panjang badan $85,06 \mathrm{~cm}$ dan lingkar dada 
$104,25 \mathrm{~cm}$. Performans ukuran tubuh sapi aceh betina (hasil penelitian ini) tergolong sudah memenuhi standar SNI katagori kelas III pada saat sapi masih berumur satu tahun (12 bulan). Berdasarkan SNI, persyaratan calon bibit untuk sapi betina umur 15-8 bulan katagori kelas III adalah tinggi pundak minimal $86 \mathrm{~cm}$, panjang badan $82 \mathrm{~cm}$ dan lingkar dada $94 \mathrm{~cm}$.

Ukuran tubuh sapi aceh betina pada penelitian ini tidak berbeda dengan penelitian sebelumnya yang dilakukan Jamaliah dan Marwan (2018) bahwa sapi betina umur 365 hari memiliki rata-rata tinggi pundak (TP) $91.14 \mathrm{~cm}$. Ukuran panjang badan mencapai $88.23 \mathrm{~cm}$ dan lingkar dada 107,05 cm. Lebih lanjut Abdullah et al. (2006) menjelaskan bahwa pertumbuhan sapi aceh umur setahun memiliki ukuran tubuh rata-rata tinggi pundak $93,77 \pm 5,82 \mathrm{~cm}$, panjang badan $93,42 \pm 8,03 \mathrm{~cm}$ dan lingkar dada mencapai $118,65 \pm 8,30 \mathrm{~cm}$. Ukuran tubuh sapi aceh umur satu tahun lebih rendah dibandingkan sapi madura, sebagaimana dilaporkan oleh Nurgiartiningsih (2010) bahwa ukuran tubuh sapi madura jantan pada umur satu tahun rmemiliki lingkar dada, panjang badan dan tinggi pundak berturut-turut $124 \mathrm{~cm}$, 101,3 dan 108,9 cm.

Penampilan produksi sapi aceh lebih rendah dibandingkan sapi lokal Indonesia lainnya (sapi bali, madura dan sapi PO). Perbedaan ini mencirikan identitas masingmasing bangsa ternak. Setiap jenis sapi memiliki sifat genetik yang berbeda baik dari sifat kualitatif maupun kuantitatif. Menurut Soeharsono (2010) menjelaskan bahwa performans produksi seekor ternak merupakan hasil interaksi antara lingkungan dengan genetik yang sering diukur dengan pertambahan bobot badan dan ukuran tubuh. Jadi jelas bahwa setiap jenis ternak memiliki kapasitas produksi yang telah terstruktur yang diturunkan dari tetuanya.

\section{KESIMPULAN}

Rata-rata penampilan produksi sapi aceh jantan dan betina yang dikembangkan di BPTU-HPT Indrapuri berpotensi menjadi ternak unggulan berdasarkan kriteria SNI. Pencapaian tersebut merupakan cerminan keberhasilan pihak BPTU dalam melakukan tugas pokok dan fungsinya sebagai produsen bibit sapi lokal unggul.

\section{UCAPAN TERIMA KASIH}

Penulis menyampaikan terima kasih kepada semua staf dan karyawan di BPTU-HPT Indrapuri atas segala bantuan dan dukungannya sehingga penelitian ini dapat diselesaikan dengan baik dan lancer.

\section{DAFTAR PUSTAKA}

Abdullah, M.A.N. 2008. Karakteristik Genetik Sapi Aceh Menggunakan Analisi Keragaman Fenotipik, Daerah DLOOP DNA Mitokondria dan DNA Mikrosatelit. Disertasi. Program Pascasarjana. Institut Pertanian Bogor.

Abdullah, M.A.N., R.R. Noor, H. Martojo, D.D. Solihin, \& E. Handiwirawan. 2006. Keragaman fenotipik sapi aceh di Nanggroe Aceh Darussalam. Journal of Indonesian Tropical Animal Agriculture 32:11-21.

Bakhtiar. 2010. Performans Reproduksi dan Produksi Sapi Aceh. Tesis. Program Pascasarjana Universitas Andalas. Padang.

BSN [Badan Standar Nasional]. 2013. SNI 7651.3:2013 Bibit sapi potong - Bagian 3:Aceh. Badan Standar Nasional. Jakarta.

Depision. 2010. Performans anak hasil persilangan induk sapi bali dengan beberapa bangsa pejantan di Kabupaten Batanghari Provinsi Jambi. Agripet 10 (1):37-41

Gunawan, A. \& Jakaria. 2011. Genetic and non-genetics effect on birth, weaning, and yearling weight of bali cattle. Media Peternakan 34(2):93- 98.

Hardjosubroto, W. 1994. Aplikasi Pemuliabiakan Ternak di Lapangan. Gramedia. Jakarta.

Jamaliah \& Marwan. 2018. Kajian kualitatif sapi aceh betina berdasarkan umur hasil uji performan pada Balai Pembibitan Ternak Unggul dan Hijauan Pakan Ternak Indrapuri. http://bptuhptindrapuri.com/site/images/files/KTI2018-jamaliah-online.pdf [20 Agustus 2018]. 
Kaswati, Sumadi, \& N. Ngadiono. 2013. Estimasi nilai heritabilitas berat lahir, berat sapih dan umur satu tahun pada sapi bali di Balai Pembibitan Ternak Unggul Sapi Bali. Buletin Peternakan 37(2):74-78.

Kurnianto, E. 2009. Pemuliaan Ternak. Graha Ilmu. Yogyakarta.

Kuswati \& T. Susilawati. 2016. Industri Sapi Potong. Universitas Brawijaya Press. Malang.

Mukhtar, Jamaliah, \& H. Saumar. 2015. Keragaman fenotipe sapi aceh betina pada BPTU-HPT Indrapuri. Jurnal Ilmiah Peternakan 3(2):34-38.

Nurgiartiningsih, V.M.A. 2010. Sistem breeding dan performans hasil persilangan sapi madura di Madura. Jurnal Ternak Tropika 11(2): 23-31.
Phillips, C.J.C. 2010. Pinciples of Cattle Production, 2 nd edition. Cambridge University Press. Cambridge.

Prasojo. G., I. Arifiantini, \& M. Kusdiantoro 2010. Korelasi antara lama kebuntingan, bobot lahir dan jenis kelamin pedet hasil inseminasi buatan pada sapi bali. Jurnal Veteriner 11(1):41-45.

Soeharsono. 2010. Fisiologi Ternak tentang Fenomena dan Nomena Dasar, Fungsi dan Interaksi Organ pada Hewan. Widya Padjadjaran. Bandung.

Sulistiyoningtiyas, I., V.M.A. Nurgiartiningsih, \& G. Ciptadi. 2017. Evaluasi performa bobot badan dan statistik vital sapi madura berdasarkan tahun kelahiran. Jurnal Ilmiah Peternakan Terpadu, 5(2): 40-43. 